\title{
Elevated PM10 and PM2.5 concentrations in Europe: a model experiment with MM5-CMAQ and WRF-CHEM
}

\author{
R. San José ${ }^{1}$, J. L. Pérez ${ }^{1}$, J. L. Morant ${ }^{1}$ \& R. M. González ${ }^{2}$ \\ ${ }^{I}$ Environmental Software and Modelling Group, \\ Computer Science School, Technical University of Madrid (UPM), \\ Campus de Montegancedo, Madrid, Spain \\ ${ }^{2}$ Department of Meteorology and Geophysics, Faculty of Physics, \\ Complutense University of Madrid; Ciudad Universitaria, Madrid, Spain
}

\begin{abstract}
We have applied the MM5-CMAQ model to simulate the high concentrations in PM10 and PM2.5 during a winter episode (2003) in Central Europe. The selected period is January 15 - April 62003 . Values of daily mean concentrations up to $75 \mathrm{\mu gm}^{-3}$ are found on average of several monitoring stations in Northern Germany. This model evaluation shows that there is an increasing underestimation of primary and secondary species with increasing observed PM10. The high PM levels were observed under stagnant weather conditions that are difficult to simulate. The MM5 is the PSU/NCAR non-hydrostatic meteorological model and CMAQ is the chemical dispersion model developed by EPA (US) used in this simulation with CBM-V. The TNO emission inventory was used to simulate the PM10 and PM2.5 concentrations with the MM5-CMAQ model. The results show a substantial underestimation of the elevated values in February and March 2003. An increase on the PM2.5 emissions (five times) produces the expected results and the correlation coefficient increases slightly. The WRF/CHEM model results show an excellent performance with correct emission database. The main difference between MM5-CMAQ simulations and $\mathrm{WRF} / \mathrm{CHEM}$ is the MOSAIC particle models and the "classical" MADE/SORGAM particle model used in WRF/CHEM and CMAQ respectively. MOSAIC seems to make a better job than MADE particle model for this particular episode.
\end{abstract}

Keywords: emissions, PM10 and PM2.5, air quality models, air particles. 


\section{Introduction}

Simulations of elevated PM10 and PM2.5 concentrations have been always underestimated by modern three dimensional air quality modelling tools. This fact has focused much more attention between researchers during last years. Three dimensional air quality models have been developed during the last 15-20 years and substantial progress has occurred in this research area. These models are composed by a meteorological driver and a chemical and transport module. Examples of meteorological drivers are: MM5 (PSU.NCAR, USA) [5], RSM (NOAA, USA), ECMWF (Redding, U.K.), HIRLAM (Finnish Meteorological Institute, Finland), WRF [15] and examples of dispersion and chemical transport modules are EURAD (University of Cologne, Germany) [13], EUROS (RIVM, The Netherlands) [7], EMEP Eulerian (DNMI, Oslo, Norway), MATCH (SMHI, Norrkoping, Sweden) [2], REM3 (Free University of Berlin, Germany) [14], CHIMERE (ISPL, Paris, France) [12], NILU-CTM (NILU, Kjeller, Norway) [3], LOTOS (TNO, Apeldoorm, The Netherlands) [8], DEM (NERI, Roskilde, Denmark) [4], OPANA model [9-11] based on MEMO and MM5 mesoscale meteorological models and with the chemistry on-line solved by [6], STOCHEM (UK Met. Office, Bracknell, U.K.) [1] and CMAQ (Community Multiscale Air Quality modelling system) [16], developed by EPA (USA). In USA, CAMx Environ Inc., STEM-III (University of Iowa) and CMAQ model are the most up-to-date air quality dispersion chemical models. In this application we have used the CMAQ model (EPA, U.S.) which is one of the most complete models and includes aerosol, cloud and aerosol chemistry.

In this contribution we present results from two simulations by two different models. The first air quality modelling systems is MM5-CMAQ which is a matured modelling system based on the MM5 mesoscale non-hydrostatic meteorological model and the dispersion and chemical transport module, CMAQ. The second tool is the WRF/CHEM [15] air quality modelling system, which is an on-line (one code, one system) tool to simulate air concentrations based on the WRF meteorological driver. In WRF/CHEM the chemistry transport and transformations are embedded into WRF as part of the code so that the interactions between many meteorological and climate variables and the chemistry if at hand and can be investigated. WRF/CHEM is developed by NOAA/NCAR (US) [15]. The advantage of on-line models is based on the capability to analyze all variables simultaneously and to account for all interactions (or at least, as much as possible) with a full modular approach.

\section{PM10 and PM2.5 episode}

During the period January 152003 to April 52003 in central Europe (mainly northern part of Germany), we observe three high peaks on PM10 and PM2.5 values in several monitoring stations located in the area of North-East of Germany. The daily averages of PM10 concentrations were close to $80 \mu^{-3} m^{-3}$ and higher than $70 \mu \mathrm{gm}^{-3}$ for PM2.5 concentrations. These values are about 4-5 times higher than those registered as "normal" values. The first peak on PM10 and PM2.5 concentrations was developed after Feb. 1 until Feb. 15. During this 
period of time, Central Europe was under the influence of a high-pressure system coming from Russia through Poland and Souther Scandinavia. In Northern part of Germany, we found southeasterly winds and stable conditions with low winds. These meteorological conditions brought daily PM10 concentrations at about 40 $\mu g m^{-3}$. The second peak was characterized by a sharp gradient on PM10 concentrations after Feb. 15 and until March 7. These episode reached daily PM10 concentrations up to $70 \mu \mathrm{gm}^{-3}$. The meteorological conditions on March 2 (peak values) was characterized by a wind rotation composed by Southwesterly winds from Poland over the North of Germany and Northwesterly and Western winds in the Central part of Germany. Finally a third peak with values of about $65 \mu^{-3}$ on March 27 starts on March 20, ending on April 52003 was having a similar structure and causes to the second one.

\section{Emission data}

In both models, we have applied the TNO emissions [17] as area and point sources with a geographical resolution of $0.125^{\circ}$ latitude by $0.25^{\circ}$ longitude and covering all Europe. The emission totals by SNAP activity sectors and countries agree with the baseline scenario for the Clean Air For Europe (CAFE) program [18]. This database gives the PM10 and PM2.5 emission for the primary particle emissions. We also took from CAFE the PM splitting sub-groups, height distribution and the breakdown of the annual emissions into hourly emissions. The PM2.5 fraction of the particle emissions was split into an unspecified fraction, elemental carbon (EC) and primary organic carbon (OC). The EC fraction of the PM2.5 emissions for the different SNAP sectors were taken from [19]. For the OC fraction, the method proposed by [20] is applied as follows: an average OC/EC emission ratio of two was used for all sectors, i.e. the OC fraction were set as twice the EC fractions, except if the sum of the two fractions exceed the unity. In this case $\left(\mathrm{f}_{\mathrm{EC}}>0.33\right), \mathrm{f}_{\mathrm{OC}}$ was set as: $f_{O C}=1-f_{E C}$. With this prepared input, the WRF/CHEM and CMAQ took the information as it is. The hourly emissions are derived using sectordependent, monthly, daily and hourly emission factors as used in the EURODELTA (http://aqm.jrc.it/eurodelta/) exercise.

\section{Observational data}

Eighteen PM10 stations were selected for the comparison with the model results. Seventeen stations represent the rural background and one station represents the urban background in Berlin. All stations are located in flat or moderate hill terrain. Most of the stations are operated by the respective Federal State agencies. At four stations (Neuglobsow, Zingst, Westerland and Deuselbach, which are EMEP background stations run by the German Environmental Protection Agency, Umweltbundesamt), the observed concentrations of particulate sulphate, total nitrate $\left(\mathrm{HNO}_{3}+\mathrm{NO}_{3}{ }^{-}\right)$and total ammonia $\left(\mathrm{NH}_{3}+\mathrm{NH}_{4}{ }^{+}\right)$ were available. Deuselbach, in the southwest of Germany, is located outside of the high PM10 concentration region. In addition, at the research station Melpitz [21] the concentrations of the components of secondary inorganic aerosols $\mathrm{SO}_{4}{ }^{--}$, $\mathrm{NO}_{3}{ }^{-}, \mathrm{NH}_{4}^{+}$, as well as the concentrations of $\mathrm{EC}, \mathrm{OC}$ and $\mathrm{NH}_{3}$ were available. 
The $\mathrm{SO}_{2}$ and $\mathrm{NO}_{2}$ concentrations at these five stations were also taken into account in the model comparison. PM2.5 observations were available at four stations: Melpitz, Waldhof, Deuselbach and Hannover. All PM10 and PM2.5 observations are based on gravimetric measurements, and the concentrations of the inorganic species in aerosol particles on ion chromotography. The chemical composition data at Melpitz result from the PM2.5 fraction, whereas the composition data from the other stations were analyzed from the PM10 particle concentrations. OC data were corrected by a factor of 1.4 to account for the non$\mathrm{C}$ atoms in the particulate organic matter (OM) concentrations, which are currently not measured [22].

\section{MM5-CMAQ and WRF-CHEM architectures and configurations}

MM5 was set up with two domains: a mother domain with 60x60 grid cells with $90 \mathrm{~km}$ spatial resolution and 23 vertical layers and $61 \times 61$ grid cells with $30 \mathrm{~km}$ spatial resolution with 23 vertical layers. The central point is set at $50.0 \mathrm{~N}$ and 10.0 E. The model is run with Lambert Conformal Conical projection. The CMAQ domain is slightly smaller following the CMAQ architecture rules. We use reanalysis T62 $(209 \mathrm{~km})$ datasets as 6-hour boundary conditions for MM5 with 28 vertical sigma levels and nudging with meteorological observations for the mother domain. We run MM5 with two-way nesting capability. We use the Kain-Fritsch 2 cumulus parameterization scheme, the MRF PBL scheme, Schultz microphysics scheme and Noah land-surface model. In CMAQ we use clean boundary profiles for initial conditions, Yamartino advection scheme, ACM2 for vertical diffusion, EBI solver and the aqueous/cloud chemistry with CB05 chemical scheme. Since our mother domain includes significant areas outside of Europe (North of Africa), we have used EDGAR emission inventory with EMIMO 2.0 emission model approach to fill those grid cells with hourly emission data. The VOC emissions are treated by SPECIATE Version 4.0 (EPA, USA) and for the lumping of the chemical species, we have used the [24] procedure for 16 different groups. We use our BIOEMI scheme for biogenic emission modeling. The classical, Atkin, Accumulation and Coarse modes are used (MADE/SORGAM modal approach).

In WRF/CHEM simulation we have used only one domain with $30 \mathrm{~km}$ spatial resolution similar to the MM5. We have used the Lin et al. (1983) scheme for the microphysics, Yamartino scheme for the boundary layer parameterization and [23] for the biogenic emissions. The MOSAIC sectional approach is used with 4 modes for particle modeling.

\section{Model results}

The comparison between daily average values (averaged over all monitoring stations) of PM10 concentrations and modeled values has been performed with several statistical tools such as: Calculated mean/Observed mean; Calculated STD/Observed STD; bias; squared correlation coefficient (R2); RMSE/Observed mean (Root Mean Squared Error); percentage within $+/-50 \%$ and number of data 


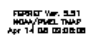

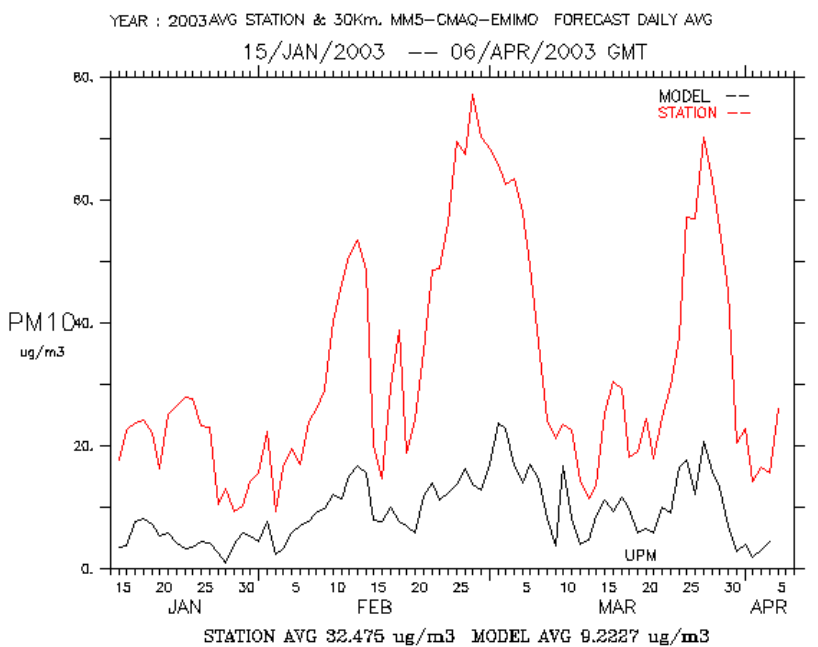

Figure 1: Comparison between daily average observed PM10 concentrations and model results produced by MM5-CMAQ. The model does not capture the magnitude of the PM10 peaks.

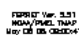

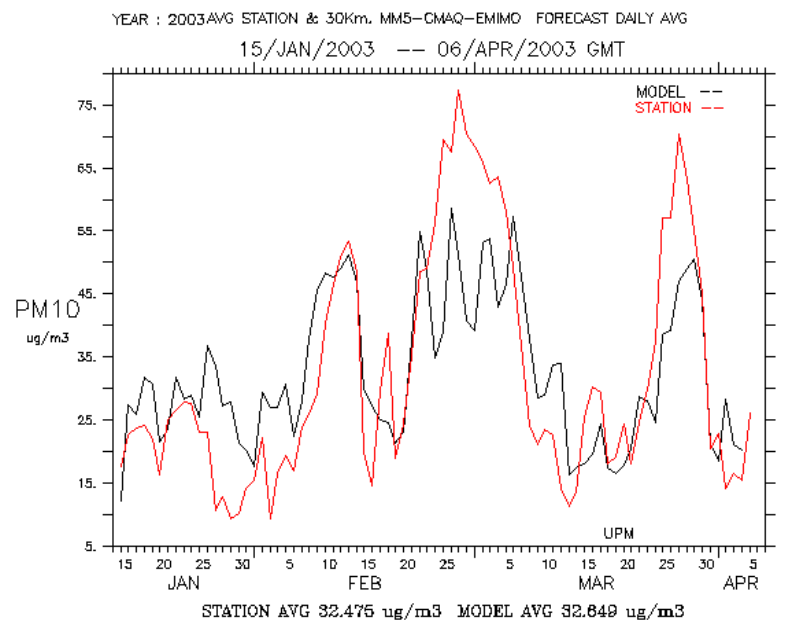

Figure 2: Comparison between daily average observed PM10 concentrations and model results produced by WRF/CHEM. The model captures quite well the magnitude of the PM10 peaks, particularly the first one.

sets. Figure 1 shows the comparison between PM10 observed averaged daily values and the modeled values by MM5-CMAQ. The results show that MM5CMAQ underestimates about 4 times the observed peak values and particularly the 


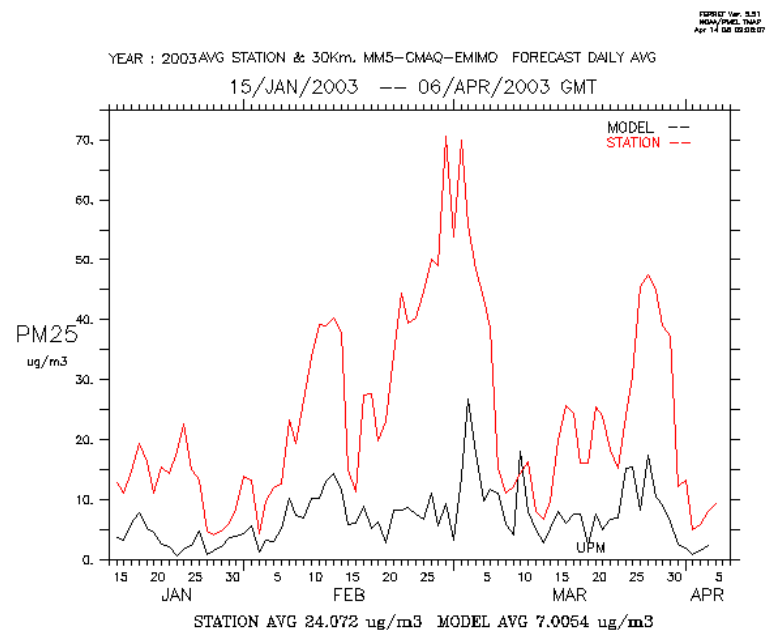

Figure 3: Comparison between daily average observed PM2.5 concentrations and model results produced by MM5-CMAQ. The model does not capture the magnitude of the PM2.5 peaks.

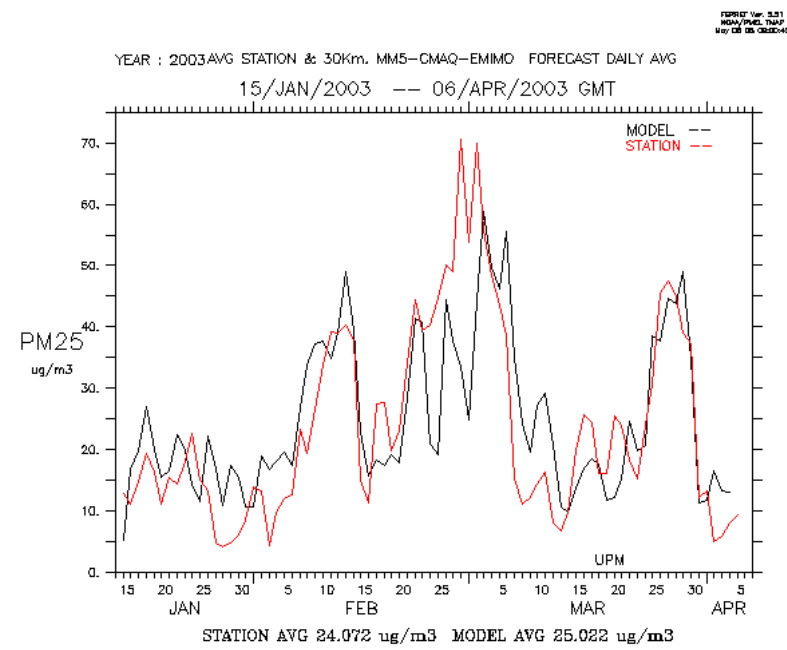

Figure 4: Comparison between daily average observed PM2.5 concentrations and model results produced by WRF/CHEM. The model captures quite well the magnitude of the PM10 peaks, particularly the last one.

highest one on March 2 2003. The R2 coefficient is 0.69. Figure 2 shows similar information but for the WRF/CHEM results. In this case WRF/CHEM captures quite well the magnitude of the peaks, particularly the first one. For the second and third peak, the model underestimates about $20 \%$ the peak values. The R2 coefficient is 0.61 . In the case of PM2.5 Figures 3 and 4 show similar results to 


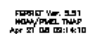

YEAR : 2003AVG STATION \& 30Km. MM5-CMAQ-EMIMO FORECAST DALYY AVG

$15 /$ JAN $/ 2003-06 /$ APR $/ 2003$ GMT

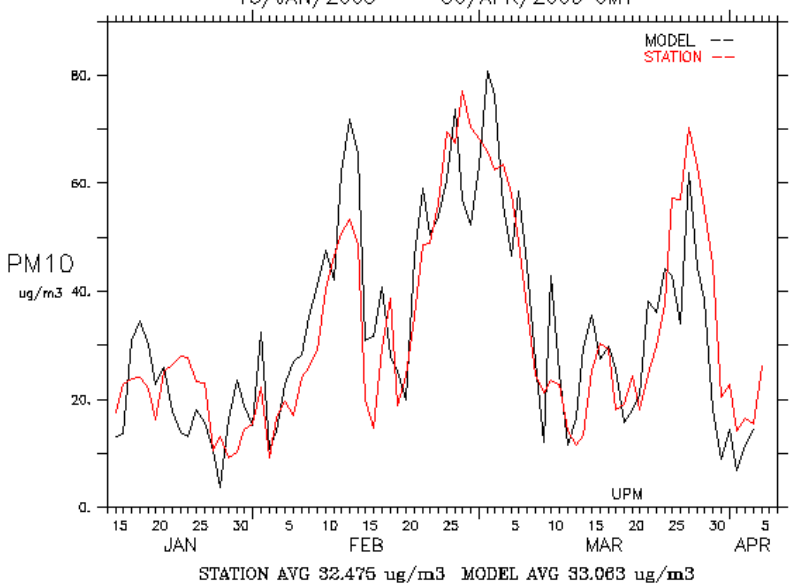

Figure 5: $\quad$ Comparison between daily average observed PM10 concentrations and model results produced by MM5-CMAQ with PM2.5 emissions multiplied by 5 . The model captures quite well the magnitude of the PM10 peaks, particularly the second one.

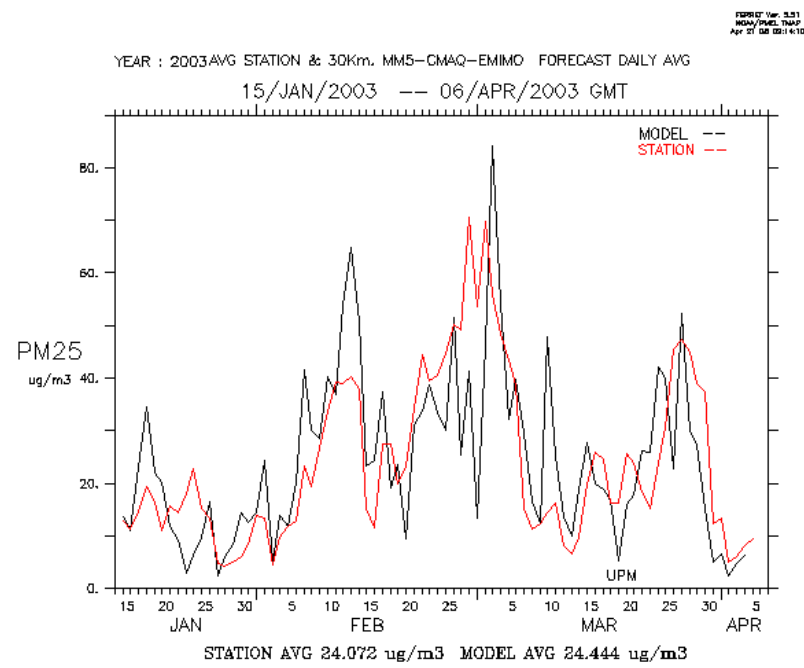

Figure 6: Comparison between daily average observed PM2.5 concentrations and model results produced by MM5-CMAQ with PM2.5 emissions multiplied by 5. The model captures quite well the magnitude of the PM10 peaks, particularly the third one. 
figures 1 and 2 . The R2 coefficients are 0.41 and 0.58 . The squared correlation coefficient goes from 0.69 to 0.61 in the case of PM10 but increases substantially In the case of PM2.5, from 0.41 to 0.58 . In WRF/CHEM both R2 coefficients (for PM10 and PM2.5) are quite close (0.58 and 0.61) but in the case of MM5-CMAQ, PM2.5 R2 coefficient is substantially lower than in the case of PM10.

We performed another full experiment with MM5-CMAQ. We multiply by 5 the PM2.5 emissions provided by TNO in the whole domain. The results are shown in Figures 5 and 6 . The results are surprisingly good for both species. The R2 coefficient is 0.70 and 0.48 for PM10 and PM2.5 respectively. In both cases the correlation is improved and particularly for PM2.5 although just slightly. It is difficult to explain these results but it is a fact.

\section{Conclusions}

We have implemented and run two different models (MM5-CMAQ and WRFCHEM) for the same episode over Northern part of Germany during the winter period of 2003 (Jan. 15-Apr. 5, 2003). WRF-CHEM made a better job than MM5-CMAQ, not only the patterns reproduce the peak values quite well but also the statistical parameters are good. The calculated mean values divided by thye observed mean value os exactly 1.0 for PM10 and WRF/CHEM on-line model. For the MM5-CMAQ this ratio is 0.28 and when we multiply the PM2.5 emissions by 5 , the ratio is 1.02 which is also excellent. The bias values for WRF/CHEM, MM5-CMAQ and MM5-CMAQ (x5) are 0.09, -23.33 and 0.51 which are excellent values for WRF/CHEM and MM5-CMAQ (x5). No realistic explanation is found for the exercise related to multiply by 5 the PM2.5 emissions from TNO emission inventory. The main apparent reason why WRF/CHEM is doing much better job than normal MM5-CMAQ is the use of MOSAIC particle model based on sectional modal approach instead the "classical" approach based on MADE/SORGAM modal approach.

\section{Acknowledgements}

We would like to thank Dr. Peter Builtjes for the initial guidance and suggestion for this experiment and also COST 728 project (EU) where the inter-comparison experiment was proposed.

\section{References}

[1] Collins W.J., D.S. Stevenson, C.E. Johnson and R.G. Derwent, Tropospheric ozone in a global scale 3D Lagrangian model and its response to NOx emission controls, J. Atmos. Chem. 86 (1997), 223-274.

[2] Derwent R., and M. Jenkin, Hydrocarbons and the long-range transport of ozone and PAN across Europe, Atmospheric Environment 8 (1991), 16611678. 
[3] Gardner R.K., K. Adams, T. Cook, F. Deidewig, S. Ernedal, R. Falk, E. Fleuti, E. Herms, C. Johnson, M. Lecht, D. Lee, M. Leech, D. Lister, B. Masse, M. Metcalfe, P. Newton, A. Schmidt, C Vandenberg. and R. van Drimmelen, The ANCAT/EC global inventory of NOx emissions from aircraft, Atmospheric Environment 31 (1997), 1751-1766.

[4] Gery M.W., G.Z. Whitten, J.P. Killus and M.C. Dodge, A photochemical kinetics mechanism for urban and regional scale computer modelling, Journal of Geophysical Research 94 (1989), D10, 12925-12956.

[5] Grell, G.A., J. Dudhia and D.R. Stauffer, A description of the FifthGeneration Penn State/NCAR Mesoscale Model (MM5), NCAR/TN- 398+ STR. NCAR Technical Note, 1994.

[6] Jacobson M.Z. and R.P. Turco, SMVGEAR: A sparse-matrix, vectorized GEAR code for atmospheric models, Atmospheric Environment 28(1994), 2, 273-284.

[7] Langner J., R. Bergstrom and K. Pleijel, European scale modeling of sulfur, oxidized nitrogen and photochemical oxidants. Model development and evaluation for the 1994 growing season, SMHI report RMK No. 82, Swedish Met. And Hydrol. Inst., SE-601 76 Norrkoping, Sweden, (1998).

[8] Roemer M., G. Boersen, P. Builtjes and P. Esser, The Budget of Ozone and Precursors over Europe Calculated with the LOTOS Model. TNO publication P96/004, Apeldoorn, The Netherlands, 1996.

[9] San José R., L. Rodriguez, J. Moreno, M. Palacios, M.A. Sanz and M. Delgado, Eulerian and photochemical modelling over Madrid area in a mesoscale context, Air Pollution II, Vol I., Computer Simulation, Computational Mechanics Publications, Ed. Baldasano, Brebbia, Power and Zannetti., 1994, 209-217.

[10] San José R., J. Cortés, J. Moreno, J.F. Prieto and R.M. González, Ozone modelling over a large city by using a mesoscale Eulerian model: Madrid case study, Development and Application of Computer Techniques to Environmental Studies, Computational Mechanics Publications, Ed. Zannetti and Brebbia, 1996, 309-319.

[11] San José, R., J.F. Prieto, N. Castellanos and J.M. Arranz, Sensitivity study of dry deposition fluxes in ANA air quality model over Madrid mesoscale area, Measurements and Modelling in Environmental Pollution, Ed. San José and Brebbia, 1997, 119-130.

[12] Schmidt H., C. Derognat, R. Vautard and M. Beekmann, A comparison of simulated and observed ozone mixing ratios for the summer 1998 in Western Europe, Atmospheric Environment 35 (2001), 6277-6297.

[13] Stockwell W., F. Kirchner, M. Kuhn and S. Seefeld, A new mechanism for regional atmospheric chemistry modeling, J. Geophys. Res. 102 (1977), 25847-25879.

[14] Walcek C., Minor flux adjustment near mixing ration extremes for simplified yet highly accurate monotonic calculation of tracer advection, $J$. Geophys. Res. 105 (2000), 9335-9348. 
[15] Janjic, Z. I., J. P. Gerrity, Jr. and S. Nickovic, 2001: An Alternative Approach to Nonhydrostatic Modeling. Monthly Weather Review, Vol. 129, 1164-1178

[16] Byun, D.W., J. Young, G. Gipson, J. Godowitch, F. Binkowsky, S. Roselle, B. Benjey, J. Pleim, J.K.S. Ching, J. Novak, C. Coats, T. Odman, A. Hanna, K. Alapaty, R. Mathur, J. McHenry, U. Shankar, S. Fine, A. Xiu, and C. Lang. 1998. Description of the Models-3 Community Multiscale Air Quality (CMAQ) model. Proceedings of the American Meteorological Society $78^{\text {th }}$ Annual Meeting Phoenix, AZ, Jan. 11-16, 264-268.

[17] Visscherdijk, A. and H. Denier van der Gon, 2005. Gridded European anthropogenic emission data for NOx, SO2, NMVOC, NH3, CO, PM10, PM2.5 and CH4 for the year 2000. TNO-report B\&O-AR, 2005/106.

[18] Amann, M., Bertok, I., Cofala, J., Gyarfas, F., Heyes, C., Klimon, Z., 2005. Baseline Scenarios for the Clean Air for Europe (CAFE) Programme. Final Report, International Institute for Applied Systems Analysis, Schlossplatz 1, A-2361 Laxenburg, Austria.

[19] Schaap, M., H. Denier van der Gon, A. Visschedijk, M. van Loon, H. ten Brink, F. Dentener, J. Putaud, B. Guillaume, C. Liousse, P. Builtjes, 2004a. Anthropogenic Black Carbon and Fine Aerosol Distribution over Europe, $J$. Geophys. Res., 109, D18207, doi:10.1029/2003JD004330.

[20] Beekmann, M., Kerschbaumer, A., Reimer, E., Stern, R., Möller, D., 2007. PM Measurement Campaign HOVERT in the Greater Berlin area: model evaluation with chemically specified observations for a one year period. Atmos. Chem. Phys. 7, 55-68.

[21] Spindler, G., K. Mueller, E. Brueggemann, T. Gnauk, H. Herrmann, 2004. Long-term size-segregated characterization of PM10, PM2.5, and PM1 at the IfT research station Melpitz downwind of Leipzig (Germany) using high and low-volume filter samplers. Atmospheric Environment 38, 53335347.

[22] Putaud, J., F. Raesa, R. Van Dingenen, E. Bruggemann, M. Facchini, S. Decesari, S. Fuzzi, R. Gehrig, C. Hueglin, P. Laj, G. Lorbeer, W. Maenhaut, N. Mihalopoulos, K. Mueller, X. Querol, S. Rodriguez, J. Schneider, G. Spindler, H. ten Brink, K. Torseth, A. Wiedensohler, 2004. A European aerosol phenomenology - 2: chemical characteristics of particulate matter at kerbside, urban, rural and background sites in Europe. Atmospheric Environment 38, 2579-2595.

[23] Guenther et al., 1995 A. Guenther, C.N. Hewitt, D. Erickson, R. Fall, C. Geron, T. Graedel, P. Harley, L. Klinger, M. Lerdau, W.A. McKay, T. Pierce, B. Scholes, R. Steinbrecher, R. Tallamraju, J. Taylor and P. Zimmerman, A global model of natural volatile organic compound emissions, Journal of Geophysical Research 100 (1995), pp. 8873-8892.

[24] Carter, W. P. L. (2007): "Development of the SAPRC-07 Chemical Mechanism and Updated Ozone Reactivity Scales," Final report to the California Air Resources Board Contract No. 03-318. August. Available at http://www.cert.ucr.edu/ carter/SAPRC. 